\title{
Correction to: Empire Builders and Their Adversaries
}

\section{Correction to:}

Chapter 3 in: D. Rock, The British in Argentina, Britain and the World,

https://doi.org/10.1007/978-3-319-97855-0_3

The incorrect text on page 89 has been replaced with the following:

"As US policy took this direction, new Foreign Secretary Lord Palmerston took action. He requested the Admiralty to direct a British warship to seize the islands."

The incorrect text on page 91 has been replaced with the following:

The handsome newly built British Protestant Chapel a few hundred metres from the central Plaza de la Victoria completed under Rosas stood out as "the only place in Spanish America where for many years to come it is likely that the exercise of our Protestant worship will be publicly tolerated."

The updated online version of the chapter can be found at https://doi.org/10.1007/978-3-319-97855-0_3 